\title{
Independence of the amount and delay ratios in the generalized matching law
}

\author{
MONICA L. RODRIGUEZ and A. W. LOGUE \\ State University of New York, Stony Brook, New York
}

\begin{abstract}
Eight pigeons chose between pairs of different sizes and delays of reinforcement scheduled according to nonindependent concurrent variable-interval variable-interval schedules. The results were best described by the generalized matching law, where the relative effects of amount and delay on preference are independent and multiplicative. Order of presentation of the conditions had a significant effect on preference that was best represented in the model by a modification of the bias parameter.
\end{abstract}

Several researchers have investigated how reinforcer size and delay combine in order to determine preference between reinforcers (e.g., Ainslie, 1974; Green, Fisher, Perlow, \& Sherman, 1981; Green \& Snyderman, 1980; Grosch \& Neuringer, 1981; Ito \& Asaki, 1982; Logue, Rodriguez, Pena-Correal, \& Mauro, 1984; Mazur \& Logue, 1978; Navarick \& Fantino, 1976; Rachlin \& Green, 1972). Models that assume a simple multiplicative relationship between the amount and delay parameters of reinforcement (e.g., the matching law, Baum \& Rachlin, 1969; the delay reduction model, Navarick \& Fantino, 1976) have been favored over models that assume an additive rule of combination (e.g., Logan, 1965). However, recent evidence has shown that a multiplicative relationship based on a power-law transformation (Green \& Snyderman, 1980; Ito \& Asaki, 1982; Logue et al. 1984) is needed for a better fit of the data.

For example, Logue et al. (1984) have presented experimental data supporting the following extension of the generalized matching law (Baum, 1974b):

$$
\frac{B_{1}}{B_{2}}=k\left(\frac{A_{1}}{A_{2}}\right)^{s_{A}}\left(\frac{D_{2}}{D_{1}}\right)^{s_{0}} \text {, }
$$

where $B_{1}$ and $B_{2}$ represent the number of choices of $\mathrm{Al}$ ternatives 1 and $2, A_{1}$ and $A_{2}$ represent the amounts of the reinforcers received from responses on those alterna-

This research was part of a doctoral dissertation submitted by the first author to the State University of New York at Stony Brook. It was supported in part by a Sigma Xi Grant-in-Aid to M. L. Rodriguez, by NIMH Grant 1 RO3 MH 3631101 to the State University of New York at Stony Brook, and by grants from the National Science Foundation. M. L. Rodriguez was partially supported by the Pontificia Universidad Católica de Chile. Some of the data reported in this paper were presented at the Annual Meeting of the Eastern Psychological Association in Boston, March 1985. We thank Howard Rachlin and Carlos Rodriguez for their valuable comments on previous drafts of this paper and Adolfo Chavarro, Telmo Pena-Correal, and Michael Smith for their assistance in conducting the experiments. Requests for reprints should be sent to Monica L. Rodriguez, who is now at the Department of Psychology, Columbia University, 406 Schermerhorn Hall, New York. NY 10027. tives, and $D_{1}$ and $D_{2}$ represent the delays to the reinforcers (time between a choice and reinforcer delivery). The parameter $k$ is a measure of response bias. A value of $k$ greater than 1 represents a constant proportional bias toward Alternative 1 , whereas a value of $k$ less than 1 represents a constant proportional bias toward Alternative 2. The parameters $s_{A}$ and $s_{D}$ represent the subject's sensitivity to variations in reinforcer amount and delay, respectively. (For further examples of multivariate powerlaw transformations of the matching law, see Davison, 1982; Hamblin \& Miller, 1977; Hunter \& Davison, 1982; Miller, 1976; Schneider, 1973; Todorov, 1973.)

Other researchers (e.g., Green \& Snyderman, 1980; Ito \& Asaki, 1982) have also discarded a simple multiplicative relationship between amount and delay of reinforcement and have indicated that amount and delay of reinforcement are not linearly equivalent in their effects upon choice. Ito and Asaki suggest that the fact that the transformation of amount of reinforcement into delay interval is nonlinear is evidence for an interaction between these two variables. However, although functions such as Equation 1 indicate that the value of reinforcer delay may depend on a nonlinear transformation of reinforcer amount, it assumes that the amount and delay ratios exert noninteractive effects on choice behavior. That is, Equation 1 assumes that the exponents of the amount or delay ratios are invariant across manipulations of the other parameter. This assumption of independence of the amount and delay ratios can be more clearly seen when Equation 1 is logarithmically linearized:

$$
\log \frac{B_{1}}{B_{2}}=\log k+s_{A} \log \frac{A_{1}}{A_{2}}+s_{D} \log \frac{D_{2}}{D_{1}} .
$$

In this logarithmic linear transformation of Equation 1 there is no interaction term representing the combined effects of the amount and delay ratios, or, in other words, the coefficient for that term is assumed to be equal to 0 . If an interaction term is included in Equation 2, this Equation becomes: 


$$
\begin{aligned}
\log \frac{B_{1}}{B_{2}}= & \log k+s_{A} \log \frac{A_{1}}{A_{2}}+s_{D} \log \frac{D_{2}}{D_{1}} \\
& +\alpha_{1} \log \frac{A_{1}}{A_{2}} \log \frac{D_{2}}{D_{1}}
\end{aligned}
$$

Interaction is defined here statistically. Two variables interact when "the effects of one variable change at different levels of the second variable" (Keppel, 1973, p. 178). To test whether there is a significant interaction effect of the amount and delay ratios, that is, whether $\alpha_{1}$ is significantly different from 0 , it is necessary to study the influence of the delays of reinforcement on preference in conjunction with variations in the amount of reinforcement. Specifically, if the amount ratio is held constant, and preference is observed as a function of the delay ratios, a different function would be obtained for different values of the amount ratio if $\alpha_{1}$ is not equal to 0 (if an interaction is present). The presence of an interaction would be represented in Equation 1 as follows:

$$
\frac{B_{1}}{B_{2}}=k\left(\frac{A_{1}}{A_{2}}\right)^{S_{A}+\alpha_{1} \log \left(D_{2} / D_{1}\right)}\left(\frac{D_{2}}{D_{1}}\right)^{S_{D}}
$$

or, equivalently,

$$
\frac{B_{1}}{B_{2}}=k\left(\frac{A_{1}}{A_{2}}\right)^{S_{A}}\left(\frac{D_{2}}{D_{1}}\right)^{S_{D}+\alpha_{1} \log \left(A_{1} / A_{2}\right)} .
$$

Thus, $s_{A}$, the exponent of the amount of reinforcement ratio, would be dependent on the manipulation of the delay ratios, and vice versa. A nonzero interaction term would have significant implications for the form of the matching law.

The assumption of independence of the effects of the amount and delay ratios on choice, as described by Equations 3 and $4 \mathrm{a}$ or $4 \mathrm{~b}$, has never been tested. Therefore, the present experiment tested this assumption by examining whether various ratios of amount of reinforcement would affect behavior differentially when the ratios of the delays of reinforcement were varied.

\section{METHOD}

\section{Subjects}

Eight adult, experimentally naive, White Carneaux pigeons, numbered $5,6,7,8,9,10,11$, and 12 , served as subjects. They were maintained at $80 \%$ of their free-feeding weights.

\section{Apparatus}

The experiment was conducted in two identical experimental chambers. Each chamber was $32 \mathrm{~cm}$ long, $32 \mathrm{~cm}$ wide, and $30 \mathrm{~cm}$ high. Two response keys, $1.9 \mathrm{~cm}$ in diameter, were mounted in one wall, $21 \mathrm{~cm}$ above the floor of the chamber, $12.5 \mathrm{~cm}$ apart. These keys required a minimum force of $.17 \mathrm{~N}$ to operate, and could be transilluminated with red, green, or white light. A food hopper, $5 \mathrm{~cm}$ in diameter and $9.5 \mathrm{~cm}$ below and to the center of the two keys, provided access to mixed grain. The chambers could be illuminated by two $7.5-\mathrm{W}$ white lights, one $7.5-\mathrm{W}$ red light, or one 7.5-W green light. The chamber-illumination lights were shown through a Plexiglas-covered hole in the aluminum ceiling of the chamber. Each chamber was enclosed in a sound-attenuating box.
Each box contained an air blower for ventilation. A PDP-8 computer in another room, using a SUPERSKED program, controlled the stimuli and recorded the responses.

\section{Procedure}

Figure 1 diagrams the procedure for one reinforcement cycle. At the beginning of a session, the left key was transilluminated green, the right key red, and the chamber was illuminated white (the choice period). When a delay period (time between a choice and reinforcer delivery) was initiated for a left peck (according to the schedule described below), both keys and the white overhead light were darkened, and the chamber was illuminated with green light. During the subsequent reinforcement period, grain was available. At the end of this period the white overhead light and the keylights were again illuminated. The sequence of events for reinforcement following a right peck was similar except that a red instead of a green overhead light was used. A peck was followed by a feedback click when the keys were lit; pecks on darkened keys had no effect.

A Stubbs and Pliskoff (1969) nonindependent concurrent variableinterval 8-sec variable-interval 8-sec (VI 8-sec VI 8-sec) schedule was used (see de Villiers, 1977). The VI schedules were constructed according to the progression suggested by Fleshler and Hoffman (1962). As each interval of a single VI schedule timed out, a reinforcer was randomly assigned with probability of .5 to the left or the right key. The VI schedule then stopped timing until after that

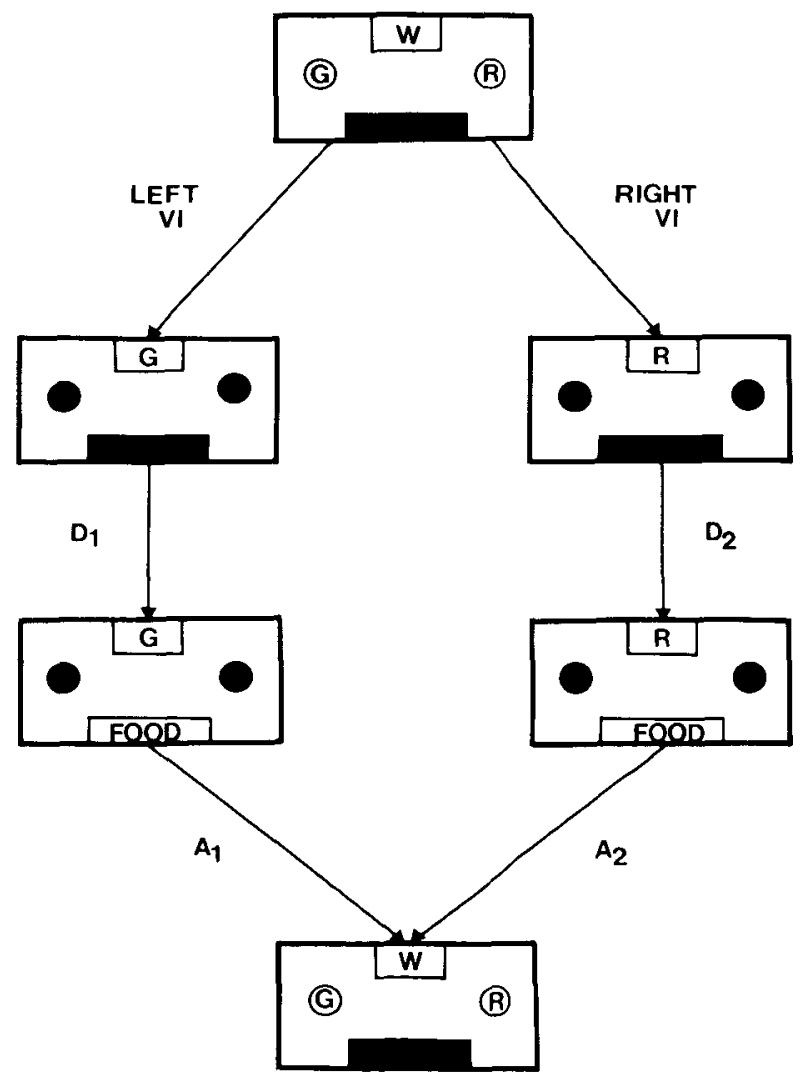

Figure 1. Diagram of the general procedure for one reinforcement cycle. During the choice period, the white overhead light $(W)$ and the green and red keys $(G, R)$ were lit. The hopper was turned off. During the subsequent delay periods $\left(D_{1}, D_{2}\right)$, the green or red overhead lights $(G, R)$ were lit and the keylights and hopper were turned off. During the following reinforcement period, the overhead lights continued on and there was food in the hopper. 
reinforcer had been received. This procedure forced the subjects to respond occasionally on both alternatives in order to obtain reinforcement from either alternative. It also ensured that the obtained relative reinforcement frequency was equal for the two alternatives, and that relative reinforcer frequency could not vary as a function of preference. Otherwise, relative reinforcer frequency would have been affected by relative preference, and relative reinforcer frequency would have had to have been entered as an additional variable in Equations 1 and 3.

A reinforcer was received for a peck on a lit key as long as both a reinforcer had been assigned to that key but not yet received, and a changeover delay (COD) had been satisfied. The COD required the subject to have made at least two responses on a particular key during a given choice period, with at least $3 \mathrm{sec}$ between the two responses and no intervening responses on the other key.

A $4 \times 4$ mixed factorial design was used; this consisted of four different ratios of reinforcer magnitude $\left(A_{1} / A_{2}\right.$, measured in seconds of access to grain) in all combinations with the same four ratios of delay of reinforcement $\left(D_{2} / D_{1}\right)$. Half of the subjects were assigned to one order of all treatment combinations of reinforcer size and delay for each alternative (Group A), and half were assigned to the reverse order (Group B, see Appendix).

Sessions were terminated after a total of 30 reinforcers had been received. A subject was exposed to a condition until it satisfied a stability criterion. This criteron specified a minimum of 10 sessions in a condition. In the last 5 consecutive sessions, the behavior ratio (number of left responses divided by number of right responses, $\boldsymbol{B}_{1} / \boldsymbol{B}_{2}$ ) had to be neither higher nor lower than (i.e., within the range of) the behavior ratio in all previous sessions of that condition. Sessions were conducted 5 to 6 days per week.

\section{RESULTS}

The analysis of the results was based on the last 5 stable days' data of each condition. The means and standard errors (in parentheses) of left and right responses during the choice periods, left and right received reinforcers, and session time are shown for each subject in each condition in the Appendix.

Figure 2 shows, for each delay ratio, $D_{2} / D_{1}$, the mean values of left divided by right responses, $B_{1} / B_{2}$, of each group, as a function of the amount ratios, $A_{1} / A_{2}$. Figure 3 shows the individual subjects' data.

The model given in Equation 3 was fitted to the data in Figures 2 and 3, using multiple linear regression. This model tested the combined effects of the ratios of the amounts $\left(A_{1} / A_{2}\right)$, the delays $\left(D_{2} / D_{1}\right)$, and their interaction, on the dependent variable $B_{1} / B_{2}$, for each subject separately. Also, separate regression analyses were performed for each of the two combined groups of subjects, and the equality of the regression lines across groups was tested. Because it was found that the groups differed significantly $[F(4,118)=6.07, p=.0002]$, the following model, which included the effect of group $\left(X_{G}\right)$, was tested for all of the subjects together:

$$
\begin{aligned}
\log \frac{B_{1}}{B_{2}}= & \log k+s_{A} \log \frac{A_{1}}{A_{2}}+s_{D} \log \frac{D_{2}}{D_{1}}+\alpha_{G} X_{G} \\
& +\alpha_{1} \log \frac{A_{1}}{A_{2}} \log \frac{D_{2}}{D_{1}}
\end{aligned}
$$

$X_{G}$ is an indicator variable. That is, $X_{G}$ is a vector in which
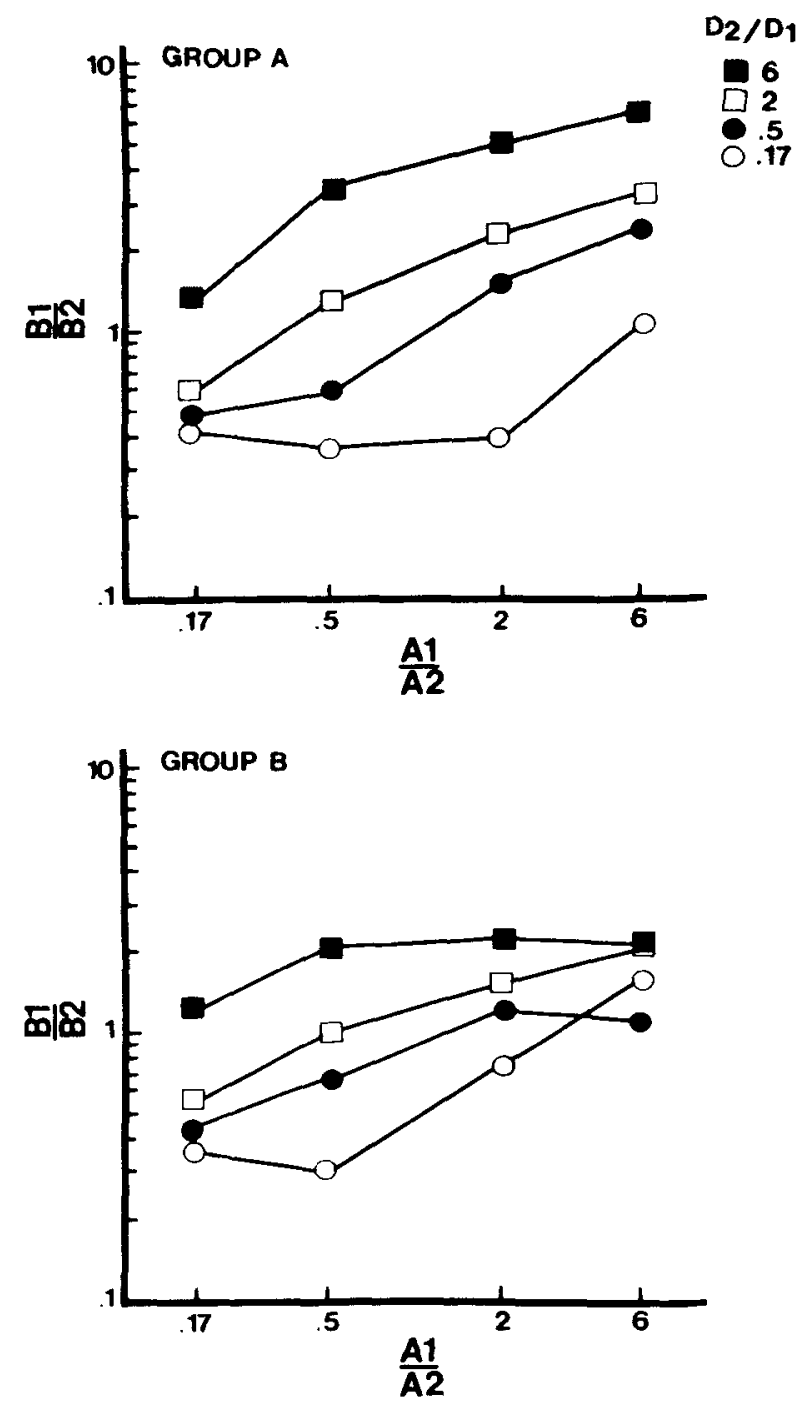

Figure 2. The mean ratios of the left and right pecks $\left(B_{1} / B_{2}\right)$ of each group (Group $A$ and Group $B$ ) as a function of the ratios of the left and right reinforcer amounts $\left(A_{1} / A_{2}\right)$ are shown in logarithmic coordinates for each ratio of left and right delays $\left(D_{2} / D_{1}\right)$.

some members of the category are assigned an arbitrary number and others are assigned a different arbitrary number. In the present case, the independent variable "group" assumed a value of 1 for Group $A$ and a value of 0 for Group B. Significance was set at $p \leq .01$ for all of the multiple regression analyses.

The results of the multiple regressions are shown in Table 1 . All of the multiple regressions performed were significant, and they accounted for most of the variance of the behavior ratio (multiple $R^{2}$ ranged from .74 to .91 ). The data were better fitted by Equation 1 than by Equation $4 a$ or Equation $4 b$, as the interaction term was found to be nonsignificant in all of the analyses performed; the probability levels ranged from .10 to .97 except for Subject 7 , whose interaction term was significant at .05 . 

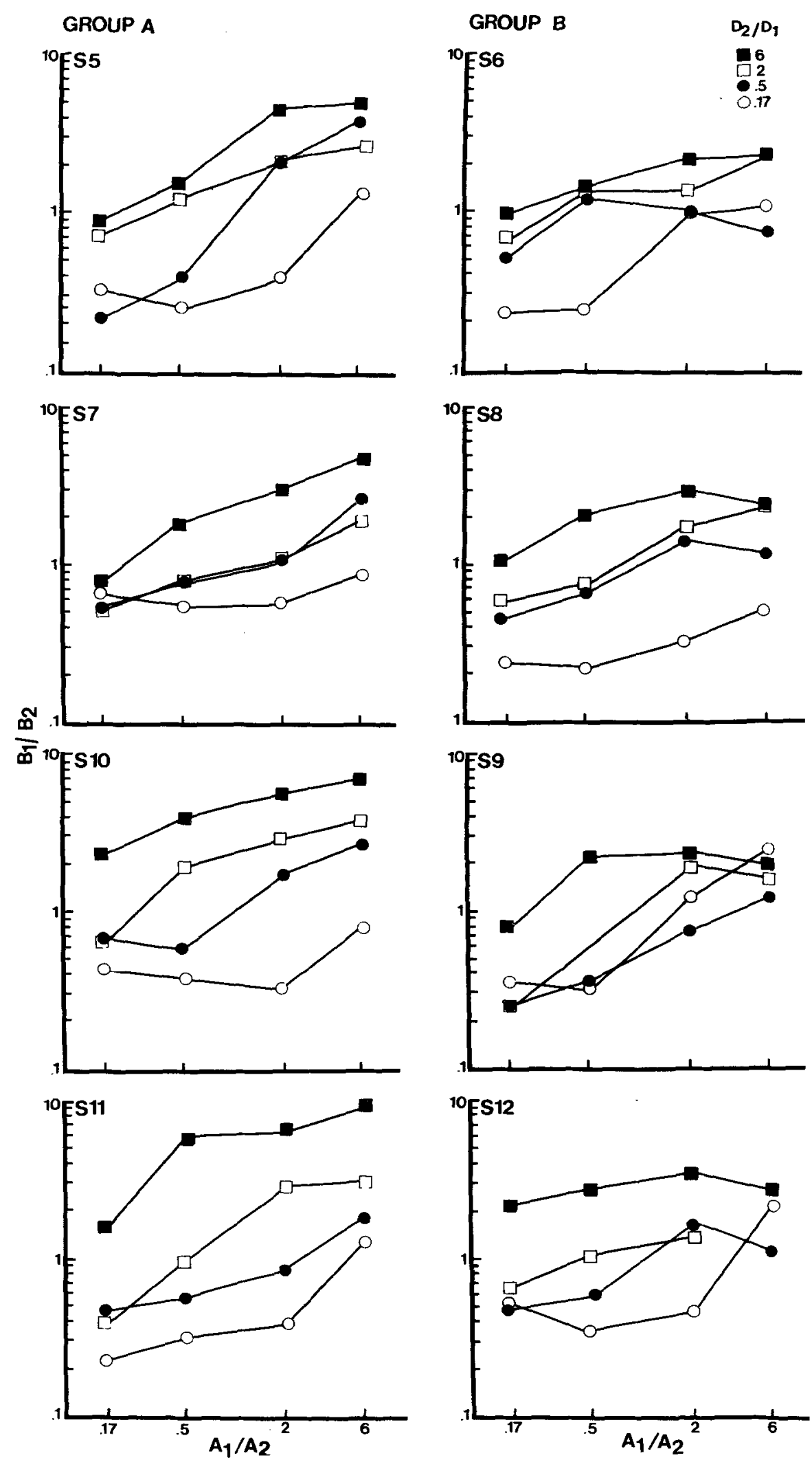

Figure 3. The mean ratios of the left and right pecks $\left(B_{1} / B_{2}\right)$ of each subject $(\mathrm{S} 5, \mathrm{S6}, \mathrm{S} 7, \mathrm{S8}$, $\mathbf{S 9}, \mathbf{S 1 0}, \mathbf{S 1 1}, \mathrm{S12}$ ) in each group (Group $\mathrm{A}$ and Group $\mathrm{B}$ ) as a function of the ratios of the left and right reinforcer amounts $\left(A_{1} / A_{2}\right)$ are shown in logarithmic coordinates for each ratio of left and right delays $\left(D_{2} / D_{1}\right)$. 
Table 1

Summary of Multiple Regression Results

\begin{tabular}{|c|c|c|c|c|c|c|c|c|c|}
\hline Regressions & $\begin{array}{c}\text { Multiple } \\
R^{2} \\
\end{array}$ & $d f$ & $F$ ratio & $p$ & $k$ & $s_{A}$ & $s_{D}$ & $\begin{array}{c}\text { Interaction } \\
\text { Amount } \times \text { Delay }\end{array}$ & $p$ \\
\hline $\begin{array}{l}\text { Order: } \\
\text { Group A } \\
\text { Group B }\end{array}$ & $\begin{array}{l}.83 \\
.74\end{array}$ & $\begin{array}{l}3,60 \\
3,58\end{array}$ & $\begin{array}{l}96.85 \\
54.69\end{array}$ & $\begin{array}{l}.0000 \\
.0000\end{array}$ & $\begin{array}{l}1.2 \\
1.0\end{array}$ & $\begin{array}{l}.42(.04)^{*} \\
.31(.04)^{*}\end{array}$ & $\begin{array}{l}.50(.04)^{*} \\
.35(.04)^{*}\end{array}$ & $\begin{array}{r}.09(.06) \\
-.11(.05)\end{array}$ & $\begin{array}{l}.14 \\
.10\end{array}$ \\
\hline $\begin{array}{l}\text { Subjects: } \\
\text { A5 } \\
\text { A7 } \\
\text { A10 } \\
\text { A11 }\end{array}$ & $\begin{array}{l}.89 \\
.83 \\
.90 \\
.91\end{array}$ & $\begin{array}{l}3,12 \\
3,12 \\
3,12 \\
3,12\end{array}$ & $\begin{array}{l}33.83 \\
19.97 \\
39.02 \\
38.09\end{array}$ & $\begin{array}{l}.0000 \\
.0001 \\
.0000 \\
.0000\end{array}$ & $\begin{array}{l}1.1 \\
1.1 \\
1.4 \\
1.2\end{array}$ & $\begin{array}{l}.53(.07)^{*} \\
.33(.06)^{*} \\
.34(.06)^{*} \\
.47(.07)^{*}\end{array}$ & $\begin{array}{l}.46(.07)^{*} \\
.30(.06)^{*} \\
.61(.06)^{*} \\
.64(.07)^{*}\end{array}$ & $\begin{array}{l}.005(.12) \\
.23(.10) \\
.11(.11) \\
.05(.13)\end{array}$ & $\begin{array}{l}.96 \\
.05 \\
.35 \\
.67\end{array}$ \\
\hline $\begin{array}{l}\text { B6 } \\
\text { B8 } \\
\text { B9 } \\
\text { B12 }\end{array}$ & $\begin{array}{l}.80 \\
.88 \\
.77 \\
.77\end{array}$ & $\begin{array}{l}3,12 \\
3,12 \\
3,11 \\
3,11\end{array}$ & $\begin{array}{l}16.12 \\
28.99 \\
19.49 \\
12.09\end{array}$ & $\begin{array}{l}.0000 \\
.0000 \\
.0001 \\
.0001\end{array}$ & $\begin{array}{r}1.0 \\
.9 \\
.9 \\
1.2\end{array}$ & $\begin{array}{l}.28(.06)^{*} \\
.28(.06)^{*} \\
.44(.08)^{*} \\
.27(.08)^{*}\end{array}$ & $\begin{array}{l}.32(.06)^{*} \\
.47(.06)^{*} \\
.24(.08) \\
.38(.07)^{*}\end{array}$ & $\begin{array}{r}-.07(.11) \\
.05(.10) \\
-.21(.14) \\
-.16(.13)\end{array}$ & $\begin{array}{l}.49 \\
.66 \\
.16 \\
.26\end{array}$ \\
\hline All Subjects $†$ & .77 & 4,121 & 101.99 & .0000 & 1.0 & $.37(.03)^{*}$ & $.43(.03)^{*}$ & $-.002(.05)$ & .97 \\
\hline
\end{tabular}

Note-Standard errors are shown in parentheses. ${ }^{*} p \leq .01 . \quad$ The regression includes the effect of group.

The coefficient for this effect was.08(.03), significant at .01.

There was a significant main effect of the amount and delay ratios when the subjects were tested separately (except for the coefficient of the delay parameter for Subject 9 , which was significant at $p=.05$ ), when each group was tested and when all of the subjects combined were tested. The coefficients for the amount and delay ratios, $s_{A}$ and $s_{D}$, respectively, were consistently less than one.

\section{DISCUSSION}

According to the present findings, the generalized matching law (Equation 1) described the present data well. The data could be fitted using this simple multiplicative model (Equation 1), without a need to add an interaction term to the model. The coefficient of the term representing the interaction between amount and delay of reinforcement was not significantly different from 0 in any of the analyses performed. Thus, according to Equation 1, the sensitivity to changes in the ratio of delays is invariant across different combinations of amount of reinforcement. Similar conclusions have been drawn when the independence of other determinants of choice have been tested, such as response force and reinforcement rate (Hunter \& Davison, 1982). In addition, the estimates for $s_{A}$ and $s_{D}$ were found to be less than 1 in the present study, consistent with findings from traditional concurrent variableinterval variable-interval experiments (Baum, 1979; de Villiers, 1977; Wearden \& Burgess, 1982).

Choice between alternative reinforcers varying in both size and delay has been examined by several researchers using concurrent chain procedures (Green \& Snyderman, 1980; Ito \& Asaki, 1982; Navarick \& Fantino, 1976; Snyderman, 1983). These studies have shown that relative preference for two alternatives changes when the $a b$ solute, but not the relative, delays for reinforcers received by responses on those alternatives change. However, when using simple concurrent variable-interval variableinterval schedules, researchers concerned with the effect of amount and delay on choice behavior have typically varied only one parameter while holding the other constant. In these studies, relative rate of response has been found to match relative immediacy of reinforcement (e.g., Chung \& Herrnstein, 1967) and relative amount of reinforcement (e.g., Brownstein, 1971; Catania, 1963). The present study assumed the adequacy of using ratios of amounts and delays to account for choice behavior, and has demonstrated that the delay ratios do not have differential effects on preference when the amount ratios are varied. Although the effects on preference of different relative versus absolute delay values in combination with various amount values were not investigated here, the generalized matching law was a good predictor for the present data.

One possible factor responsible for the significant effect of group (see above) could have been the order of presentation of the conditions, which differed in each group. The order of presentation of the conditions could have had differential effects on preference, although it is also possible that the subjects in the two groups simply differed. Supporting the argument that the groups differed due to the different orders in which they were exposed to the conditions is the fact that the bias parameter, $k$, although consistently around 1 , was greater in Group A than in Group B, significant at .05 $[t(6)=2.32$, $p<.05]$. That is, when the values of the amounts and delays were such that Equation 1 initially predicted a preference for Alternative 1 that progressively decreased, with an increasing preference for Alternative 2 (see Appendix), the subjects' choices were biased toward Alternative 1 (Group A). The reverse occurred in Group B. Baum $(1972,1974 a)$ has presented evidence for similar kinds of order effects. On the basis of Equation 5, Equation 1 can be reformulated to incorporate the effect of order:

$$
\frac{B_{1}}{B_{2}}=k 10^{\alpha}{ }_{G}{ }^{X} G\left(\frac{A_{1}}{A_{2}}\right)^{s_{A}}\left(\frac{D_{2}}{D_{1}}\right)^{s_{D}} .
$$


Note that the only difference between Equations 1 and 6 is that $k$ is multiplied by a constant, $10^{\alpha}{ }_{G}{ }_{G}$. In the present case, the coefficient $\alpha_{\mathrm{G}}$ was equal to .8 . Thus, following Equation 6 , the bias parameter has to be multiplied by $10^{.8}$ in Group A and by 1 in Group B, where $X_{G}$ equaled 0 . Therefore, the bias produced by the experimental asymmetry was not substantial, and it was in the expected direction.

In conclusion, the present results support the multivariate power-law transformation of the matching law, Equation 1, which assumes that amount and delay ratios exert independent, multiplicative effects on choice. Both the amount and delay ratios need to be raised to an exponent less than 1. If the order of presentation is such that relative preference progressively increases or decreases for a given alternative, a model that modifies the bias parameter, as in Equation 6, can be applied.

\section{REFERENCES}

AINSLie, G. (1974). Impulse control in pigeons. Journal of the Experimental Analysis of Behavior, 21, 485-489.

Baum, W. M. (1972). Choice in a continuous procedure. Psychonomic Science, 28, 263-265.

Baum, W. M. (1974a). Chained concurrent schedules: Reinforcement as situation transition. Journal of the Experimental Analysis of Behavior, 22, 91-101.

BAUM, W. M. (1974b). On two types of deviation from the matching law: Bias and undermatching. Journal of the Experimental Analysis of Behavior, 22, 231-242.

BAUM, W. M. (1979). Matching, undermatching and overmatching in studies of choice. Journal of the Experimental Analysis of Behavior, 32, 269-281.

BAUM, W. M., \& RACHLIN, H. (1969). Choice as time allocation. Journal of the Experimental Analysis of Behavior, 12, 861-874.

Brownstein, A. J. (1971). Concurrent schedules of responseindependent reinforcement: Duration of a reinforcing stimulus. Journal of the Experimental Analysis of Behavior, 15, 211-215.

CATANIA, A. C. (1963). Concurrent performances: A baseline for the study of reinforcement magnitude. Journal of the Experimental Analysis of Behavior, 6, 299-300.

Chung, S., \& Herrnstein, R. J. (1967). Choice and delay of reinforcement. Joumal of the Experimental Analysis of Behavior, 10, 67-74.

DAvison, M. (1982). Preference in concurrent variable-interval fixedratio schedules. Journal of the Experimental Analysis of Behavior, 40, 15-34.

DE VILLIERS, P. (1977). Choice in concurrent schedules and a quantitative formulation of the law of effect. In W. K. Honig \& J. E. R.
Staddon (Eds.), Handbook of operant behavior. Englewood Cliffs, NJ: Prentice-Hall.

Fleshler, M., \& Hoffman, H. S. (1962). A progression for generating variable-interval schedules. Journal of the Experimental Analysis of Behavior, 5, 529-530.

Green, L., Fisher, E. B., Jr., Perlow, S., \& Sherman, L. (1981). Preference reversal and self-control: Choice as a function of reward amount and delay. Behaviour Analysis Letters, 1, 43-51.

Green, L., \& SNYDERMAN, M. (1980). Choice between rewards differing in amount and delay: Toward a choice model of self-control. Journal of the Experimental Analysis of Behavior, 34, 135-147.

Grosch, J., \& NeURINGER, A. (1981). Self-control in pigeons under the Mischel paradigm. Journal of the Experimental Analysis of Behavior, 35, 3-21.

Hamblin, R. L., \& MilleR, H. L., JR. (1977). Matching as a multivariate power law: Frequency of behavior versus frequency and magnitude of reinforcement. Learning \& Motivation, 8, 113-125.

HunTER, I., \& DAVISON, M. (1982). Independence of response force and reinforcement rate on concurrent variable-interval schedule performance. Journal of the Experimental Analysis of Behavior, 37, 183-197.

ITo, M., \& ASAKI, K. (1982). Choice behavior of rats in a concurrentchains schedule: Amount and delay of reinforcement. Journal of the Experimental Analysis of Behavior, 37, 383-392.

KEPPEL, G. (1973). Design and analysis: A researcher's handbook. Englewood Cliffs, NJ: Prentice-Hall.

LoGan, F. A. (1965). Decision making by rats: Delay versus amount of reward. Journal of Comparative \& Physiological Psychology, 59, $1-12$.

Logue, A. W., Rodriguez, M. L., Pena-Correal, T., \& Mauro, B. C. (1984). Choice in a self-control paradigm: Quantification of experience-based differences. Journal of the Experimental Analysis of Behavior, 41, 53-67.

Mazur, J. E., \& Logue, A. W. (1978). Choice in a "self-control" paradigm: Effects of a fading procedure. Joumal of the Experimental Analysis of Behavior, 30, 11-17.

Miller, H. L., JR. (1976). Matching-based hedonic scaling in the pigeon. Journal of the Experimental Analysis of Behavior, 26, 335-347. NAVARICK, D. J., \& FANTINO, E. (1976). Self-control and general models of choice. Journal of Experimental Psychology: Animal Behavior Processes, 2, 75-87.

Rachlin, H., \& GREEN, L. (1972). Commitment, choice and selfcontrol. Journal of the Experimental Analysis of Behavior, 17, 15-22.

SCHNEIDER, J. W. (1973). Reinforcer effectiveness as a function of reinforcer rate and magnitude: A comparison of concurrent performances. Journal of the Experimental Analysis of Behavior, 20, 461-471.

SNYDERMAN, M. (1983). Delay and amount of reward in a concurrent chain. Journal of the Experimental Analysis of Behavior, 39, 437-447.

Stubrs, D. A., \& Pliskoff, S. S. (1969). Concurrent responding with fixed relative rate of reinforcement. Joumal of the Experimental Analysis of Behavior, 12, 887-895.

TODOROV, J. C. (1973). Interaction of frequency and magnitude of reinforcement on concurrent performances. Journal of the Experimental Analysis of Behavior, 19, 451-458.

WEARDEN, J. H., \& BuRGESS, I. S. (1982). Matching since Baum (1979). Journal of the Experimental Analysis of Behavior, 38, 339-348.

\begin{tabular}{|c|c|c|c|c|c|c|c|}
\hline \multirow{3}{*}{$\begin{array}{c}\text { Condition* } \\
\left(A_{1}, A_{2}, D_{1}, D_{2}\right)\end{array}$} & \multicolumn{6}{|c|}{$\begin{array}{l}\text { APPENDIX } \\
\text { Number of Sessions in Each Condition, Session Time, and } \\
\text { Responses and Reinforcers per Session for Each Subject }\end{array}$} & \multirow{3}{*}{$\begin{array}{c}\text { Sessiont } \\
\text { Time }\end{array}$} \\
\hline & \multirow[b]{2}{*}{ Subjects } & \multirow{2}{*}{$\begin{array}{c}\text { Number of } \\
\text { Sessions }\end{array}$} & \multicolumn{2}{|c|}{ Responses per Session } & \multicolumn{2}{|c|}{ Reinforcers per Session } & \\
\hline & & & Left & Right & Left & Right & \\
\hline \multicolumn{8}{|c|}{ Group A } \\
\hline \multirow[t]{4}{*}{$2,12,2,12$} & 5 & 12 & $228.6(16.5)$ & $251.8(15.0)$ & $16.4(1.3)$ & $13.6(1.3)$ & $13.3(0.4)$ \\
\hline & 7 & 24 & $321.0(27.0)$ & $411.4(31.0)$ & $14.4(0.5)$ & $15.6(0.5)$ & $13.5(0.5)$ \\
\hline & 10 & 12 & $530.6(28.6)$ & $234.4(17.8)$ & $16.4(0.6)$ & $13.6(0.6)$ & $14.7(0.3)$ \\
\hline & 11 & 15 & $230.2(12.8)$ & $150.6(8.5)$ & $14.8(0.8)$ & $15.2(0.8)$ & $17.5(0.6)$ \\
\hline
\end{tabular}


APPENDIX (continued)

\begin{tabular}{|c|c|c|c|c|c|c|c|}
\hline \multirow{2}{*}{$\begin{array}{c}\text { Condition* } \\
\left(A_{1}, A_{2}, D_{1}, D_{2}\right)\end{array}$} & \multirow[b]{2}{*}{ Subjects } & \multirow{2}{*}{$\begin{array}{l}\text { Number of } \\
\text { Sessions }\end{array}$} & \multicolumn{2}{|c|}{ Responses per Session } & \multicolumn{2}{|c|}{ Reinforcers per Session } & \multirow{2}{*}{$\begin{array}{l}\text { Session } \dagger \\
\text { Time }\end{array}$} \\
\hline & & & Left & Right & Left & Right & \\
\hline $2,4,2,12$ & $\begin{array}{r}5 \\
7 \\
10 \\
11\end{array}$ & $\begin{array}{l}19 \\
32 \\
15 \\
12\end{array}$ & $\begin{array}{l}286.8(14.6) \\
587.0(30.0) \\
581.2(37.1) \\
525.0(32.2)\end{array}$ & $\begin{array}{r}179.4(5.1) \\
313.4(22.6) \\
147.0(9.6) \\
90.4(9.9)\end{array}$ & $\begin{array}{l}15.8(1.2) \\
18.8(1.5) \\
15.8(1.0) \\
15.8(1.0)\end{array}$ & $\begin{array}{l}14.2(1.2) \\
11.2(1.5) \\
14.2(1.0) \\
14.2(1.0)\end{array}$ & $\begin{array}{l}12.2(0.4) \\
11.2(0.3) \\
15.7(2.1) \\
15.8(2.0)\end{array}$ \\
\hline $4,2,2,12$ & $\begin{array}{r}5 \\
7 \\
10 \\
11\end{array}$ & $\begin{array}{l}16 \\
28 \\
19 \\
12\end{array}$ & $\begin{array}{l}492.5(18.9) \\
813.4(39.0) \\
800.5(24.8) \\
616.4(28.0)\end{array}$ & $\begin{array}{l}102.0(5.1) \\
266.4(21.3) \\
138.3(1.6) \\
101.8(8.6)\end{array}$ & $\begin{array}{l}14.8(0.7) \\
15.0(0.4) \\
14.5(0.3) \\
15.0(1.0)\end{array}$ & $\begin{array}{l}15.3(0.7) \\
15.0(0.4) \\
15.5(0.3) \\
15.0(1.0)\end{array}$ & $\begin{array}{l}13.2(0.5) \\
12.6(0.5) \\
15.1(0.2) \\
13.5(0.5)\end{array}$ \\
\hline $12,2,2,12$ & $\begin{array}{r}5 \\
7 \\
10 \\
11\end{array}$ & $\begin{array}{l}12 \\
19 \\
15 \\
27\end{array}$ & $\begin{array}{l}547.0(26.6) \\
774.2(22.2) \\
911.3(25.6) \\
746.0(18.7)\end{array}$ & $\begin{array}{r}113.2(9.1) \\
161.0(8.4) \\
132.5(12.8) \\
81.0(4.9)\end{array}$ & $\begin{array}{l}13.8(1.4) \\
16.0(0.6) \\
14.0(0.9) \\
14.4(1.0)\end{array}$ & $\begin{array}{l}16.2(1.4) \\
14.0(0.6) \\
16.0(0.9) \\
15.6(1.0)\end{array}$ & $\begin{array}{l}17.9(1.5) \\
13.8(0.1) \\
17.6(0.3) \\
23.3(4.1)\end{array}$ \\
\hline $2,12,2,4$ & $\begin{array}{r}5 \\
7 \\
10 \\
11\end{array}$ & $\begin{array}{l}14 \\
18 \\
14 \\
25\end{array}$ & $\begin{array}{l}187.0(14.0) \\
278.6(22.9) \\
265.4(19.0) \\
156.8(18.4)\end{array}$ & $\begin{array}{l}250.3(14.6) \\
537.6(18.0) \\
434.4(13.6) \\
402.3(18.4)\end{array}$ & $\begin{array}{l}15.3(1.6) \\
15.4(0.9) \\
15.0(1.0) \\
14.0(1.1)\end{array}$ & $\begin{array}{l}14.8(1.6) \\
14.6(0.9) \\
15.0(1.0) \\
16.0(1.1)\end{array}$ & $\begin{array}{r}13.3(0.5) \\
9.3(0.1) \\
11.8(0.6) \\
13.8(0.7)\end{array}$ \\
\hline $2,4,2,4$ & $\begin{array}{r}5 \\
7 \\
10 \\
11\end{array}$ & $\begin{array}{l}14 \\
21 \\
27 \\
19\end{array}$ & $\begin{array}{l}241.8(16.2) \\
309.0(20.0) \\
417.0(14.1) \\
287.5(16.1)\end{array}$ & $\begin{array}{l}192.0(6.9) \\
388.5(18.0) \\
212.4(11.6) \\
291.3(9.2)\end{array}$ & $\begin{array}{l}17.2(0.9) \\
16.8(0.8) \\
15.0(0.6) \\
13.0(1.3)\end{array}$ & $\begin{array}{l}12.8(0.9) \\
13.3(0.8) \\
15.0(0.6) \\
17.0(1.3)\end{array}$ & $\begin{array}{l}9.2(0.2) \\
7.6(0.2) \\
8.9(0.3) \\
9.0(0.2)\end{array}$ \\
\hline $4,2,2,4$ & $\begin{array}{r}5 \\
7 \\
10 \\
11\end{array}$ & $\begin{array}{l}15 \\
15 \\
10 \\
15\end{array}$ & $\begin{array}{l}342.2(24.9) \\
311.8(12.3) \\
557.4(15.5) \\
565.2(12.1)\end{array}$ & $\begin{array}{l}154.0(8.5) \\
300.0(20.1) \\
195.8(12.1) \\
199.6(4.2)\end{array}$ & $\begin{array}{l}12.8(0.9) \\
13.8(1.0) \\
15.4(1.3) \\
15.0(0.9)\end{array}$ & $\begin{array}{l}17.2(0.9) \\
16.2(1.0) \\
14.6(1.3) \\
15.0(0.9)\end{array}$ & $\begin{array}{r}10.6(0.3) \\
7.5(0.2) \\
9.5(0.3) \\
9.8(0.2)\end{array}$ \\
\hline $12,2,2,4$ & $\begin{array}{r}5 \\
7 \\
10 \\
11\end{array}$ & $\begin{array}{l}20 \\
18 \\
14 \\
18\end{array}$ & $\begin{array}{l}394.2(23.5) \\
749.4(41.0) \\
529.8(8.4) \\
563.0(13.0)\end{array}$ & $\begin{array}{l}102.4(6.4) \\
380.2(23.2) \\
143.2(8.2) \\
185.0(9.7)\end{array}$ & $\begin{array}{l}17.0(1.2) \\
15.2(1.3) \\
14.4(0.4) \\
14.6(0.8)\end{array}$ & $\begin{array}{l}13.0(1.2) \\
14.8(1.3) \\
15.6(0.4) \\
15.4(0.8)\end{array}$ & $\begin{array}{l}13.5(0.7) \\
14.8(2.3) \\
11.8(0.2) \\
13.0(0.4)\end{array}$ \\
\hline $2,12,4,2$ & $\begin{array}{r}5 \\
7 \\
10 \\
11\end{array}$ & $\begin{array}{l}21 \\
15 \\
17 \\
14\end{array}$ & $\begin{array}{r}85.6(13.1) \\
281.8(13.0) \\
260.5(9.4) \\
217.2(10.4)\end{array}$ & $\begin{array}{l}349.6(17.4) \\
515.4(27.5) \\
403.3(13.2) \\
490.6(57.3)\end{array}$ & $\begin{array}{l}15.8(1.1) \\
15.2(0.7) \\
16.3(1.1) \\
15.4(0.2)\end{array}$ & $\begin{array}{l}14.2(1.1) \\
14.8(0.7) \\
13.8(1.1) \\
14.6(0.2)\end{array}$ & $\begin{array}{l}13.6(0.7) \\
10.0(0.3) \\
11.7(0.3) \\
18.8(1.6)\end{array}$ \\
\hline $2,4,4,2$ & $\begin{array}{r}5 \\
7 \\
10 \\
11\end{array}$ & $\begin{array}{l}17 \\
10 \\
13 \\
12\end{array}$ & $\begin{array}{l}137.2(17.6) \\
308.6(18.3) \\
253.8(10.6) \\
216.2(9.2)\end{array}$ & $\begin{array}{l}356.2(21.9) \\
406.8(18.5) \\
437.6(12.2) \\
388.0(17.0)\end{array}$ & $\begin{array}{l}15.4(0.7) \\
16.4(1.3) \\
16.4(1.2) \\
16.0(1.0)\end{array}$ & $\begin{array}{l}14.6(0.7) \\
14.6(1.3) \\
13.6(1.2) \\
14.0(1.0)\end{array}$ & $\begin{array}{r}9.3(0.5) \\
10.4(0.7) \\
9.9(0.2) \\
8.3(0.2)\end{array}$ \\
\hline $4,2,4,2$ & $\begin{array}{r}5 \\
7 \\
10 \\
11\end{array}$ & $\begin{array}{l}32 \\
26 \\
25 \\
17\end{array}$ & $\begin{array}{l}323.6(16.8) \\
389.0(29.2) \\
406.0(19.3) \\
344.8(13.9)\end{array}$ & $\begin{array}{l}136.4(10.8) \\
378.8(10.9) \\
236.8(11.2) \\
406.8(21.1)\end{array}$ & $\begin{array}{l}14.0(1.0) \\
15.0(1.5) \\
14.4(1.6) \\
18.4(1.3)\end{array}$ & $\begin{array}{l}16.0(1.0) \\
15.0(1.5) \\
15.6(1.6) \\
11.6(1.3)\end{array}$ & $\begin{array}{r}10.2(0.6) \\
7.5(0.3) \\
9.6(0.4) \\
9.5(0.5)\end{array}$ \\
\hline $12,2,4,2$ & $\begin{array}{r}5 \\
7 \\
10 \\
11\end{array}$ & $\begin{array}{l}14 \\
12 \\
22 \\
11\end{array}$ & $\begin{array}{l}286.8(11.7) \\
723.4(27.3) \\
479.0(31.3) \\
452.0(20.7)\end{array}$ & $\begin{array}{l}107.6(3.3) \\
271.4(4.2) \\
192.4(20.4) \\
247.6(7.1)\end{array}$ & $\begin{array}{l}13.6(0.5) \\
15.4(0.7) \\
14.4(1.5) \\
13.2(1.0)\end{array}$ & $\begin{array}{l}16.4(0.5) \\
14.6(0.7) \\
15.6(1.5) \\
16.8(1.0)\end{array}$ & $\begin{array}{l}12.1(0.3) \\
10.0(0.2) \\
15.9(2.2) \\
10.6(0.3)\end{array}$ \\
\hline $2,12,12,2$ & $\begin{array}{r}5 \\
7 \\
10 \\
11\end{array}$ & $\begin{array}{l}19 \\
11 \\
11 \\
17\end{array}$ & $\begin{array}{r}80.2(12.5) \\
345.0(19.1) \\
212.6(8.9) \\
96.6(7.2)\end{array}$ & $\begin{array}{l}241.6(15.0) \\
523.8(25.7) \\
524.6(42.5) \\
414.4(43.8)\end{array}$ & $\begin{array}{l}12.4(1.1) \\
17.0(1.7) \\
16.4(0.8) \\
14.6(0.9)\end{array}$ & $\begin{array}{l}17.6(1.1) \\
13.0(1.7) \\
13.6(0.8) \\
15.4(0.9)\end{array}$ & $\begin{array}{l}12.6(0.4) \\
12.2(0.4) \\
21.2(1.9) \\
24.7(8.2)\end{array}$ \\
\hline $2,4,12,2$ & $\begin{array}{r}5 \\
7 \\
10 \\
11\end{array}$ & $\begin{array}{l}13 \\
24 \\
21 \\
23\end{array}$ & $\begin{array}{r}90.6(13.6) \\
233.0(14.7) \\
162.2(9.7) \\
114.2(8.4)\end{array}$ & $\begin{array}{l}313.4(60.2) \\
418.4(10.8) \\
425.4(17.7) \\
371.4(9.8)\end{array}$ & $\begin{array}{l}12.8(1.1) \\
14.8(1.3) \\
14.4(0.9) \\
13.2(1.3)\end{array}$ & $\begin{array}{l}17.2(1.1) \\
15.2(1.3) \\
15.6(0.9) \\
16.8(1.3)\end{array}$ & $\begin{array}{r}11.3(1.2) \\
10.3(0.8) \\
10.9(0.4) \\
9.8(0.3)\end{array}$ \\
\hline $4,2,12,2$ & $\begin{array}{r}5 \\
7 \\
10 \\
11\end{array}$ & $\begin{array}{l}22 \\
19 \\
12 \\
16\end{array}$ & $\begin{array}{l}100.2(9.1) \\
235.8(10.0) \\
140.5(7.4) \\
148.2(8.2)\end{array}$ & $\begin{array}{l}250.2(15.4) \\
450.2(8.9) \\
446.7(24.9) \\
382.0(22.7)\end{array}$ & $\begin{array}{l}14.6(0.9) \\
16.2(1.0) \\
14.5(1.1) \\
12.8(1.0)\end{array}$ & $\begin{array}{l}15.4(0.9) \\
13.8(1.0) \\
15.5(1.1) \\
17.2(1.0)\end{array}$ & $\begin{array}{l}11.2(0.5) \\
10.2(0.4) \\
10.7(0.5) \\
10.4(0.5)\end{array}$ \\
\hline $12,2,12,2$ & $\begin{array}{r}5 \\
7 \\
10 \\
11\end{array}$ & $\begin{array}{l}28 \\
17 \\
17 \\
19\end{array}$ & $\begin{array}{l}183.6(5.1) \\
289.2(35.9) \\
278.8(12.0) \\
299.4(20.0)\end{array}$ & $\begin{array}{l}137.2(8.2) \\
327.2(14.7) \\
364.8(16.5) \\
235.2(11.9)\end{array}$ & $\begin{array}{l}15.6(0.9) \\
13.6(1.0) \\
17.0(1.5) \\
13.6(1.0)\end{array}$ & $\begin{array}{l}14.4(0.9) \\
16.4(1.0) \\
13.0(1.5) \\
16.4(1.0)\end{array}$ & $\begin{array}{l}16.5(0.4) \\
11.8(0.5) \\
17.8(1.4) \\
15.5(0.9)\end{array}$ \\
\hline
\end{tabular}


APPENDIX (continued)

\begin{tabular}{|c|c|c|c|c|c|c|c|}
\hline \multirow{2}{*}{$\begin{array}{c}\text { Condition* } \\
\left(A_{1}, A_{2}, D_{1}, D_{2}\right)\end{array}$} & \multirow[b]{2}{*}{ Subjects } & \multirow{2}{*}{$\begin{array}{l}\text { Number of } \\
\text { Sessions }\end{array}$} & \multicolumn{2}{|c|}{ Responses per Session } & \multicolumn{2}{|c|}{ Reinforcers per Session } & \multirow{2}{*}{$\begin{array}{c}\text { Sessiont } \\
\text { Time }\end{array}$} \\
\hline & & & Left & Right & Left & Right & \\
\hline \multicolumn{8}{|c|}{ Group B } \\
\hline $12,2,12,2$ & $\begin{array}{r}6 \\
8 \\
9 \\
12\end{array}$ & $\begin{array}{l}21 \\
15 \\
14 \\
11\end{array}$ & $\begin{array}{l}311.0(8.8) \\
225.6(16.6) \\
538.6(16.7) \\
429.0(9.2)\end{array}$ & $\begin{array}{l}281.2(13.7) \\
437.2(14.3) \\
213.2(8.2) \\
199.6(4.9)\end{array}$ & $\begin{array}{l}15.0(0.8) \\
15.2(0.7) \\
15.8(1.7) \\
15.2(0.7)\end{array}$ & $\begin{array}{l}15.0(0.8) \\
14.8(0.7) \\
14.2(1.7) \\
14.8(0.7)\end{array}$ & $\begin{array}{l}15.4(0.4) \\
13.1(0.3) \\
13.6(0.6) \\
13.8(0.2)\end{array}$ \\
\hline $4,2,12,2$ & $\begin{array}{r}6 \\
8 \\
9 \\
12\end{array}$ & $\begin{array}{l}12 \\
21 \\
17 \\
36\end{array}$ & $\begin{array}{l}264.2(12.6) \\
199.2(13.1) \\
389.0(28.5) \\
162.2(11.3)\end{array}$ & $\begin{array}{l}275.4(8.5) \\
611.6(21.5) \\
305.0(14.3) \\
361.6(18.5)\end{array}$ & $\begin{array}{l}15.2(0.7) \\
14.6(1.6) \\
17.0(1.0) \\
15.6(0.5)\end{array}$ & $\begin{array}{l}14.8(0.7) \\
15.4(1.6) \\
13.0(1.0) \\
14.4(0.5)\end{array}$ & $\begin{array}{l}10.5(0.3) \\
10.0(0.4) \\
12.7(0.2) \\
11.3(0.5)\end{array}$ \\
\hline $2,4,12,2$ & $\begin{array}{r}6 \\
8 \\
9 \\
12\end{array}$ & $\begin{array}{l}11 \\
12 \\
16 \\
25\end{array}$ & $\begin{array}{l}125.8(10.8) \\
176.0(13.6) \\
144.0(16.8) \\
132.5(7.6)\end{array}$ & $\begin{array}{l}448.2(24.1) \\
768.4(37.0) \\
464.8(30.3) \\
376.5(18.2)\end{array}$ & $\begin{array}{l}15.4(1.2) \\
15.0(0.8) \\
14.2(1.5) \\
16.3(0.7)\end{array}$ & $\begin{array}{l}14.6(1.2) \\
15.0(0.8) \\
15.8(1.5) \\
13.8(0.7)\end{array}$ & $\begin{array}{l}11.4(0.5) \\
10.9(0.3) \\
13.2(1.3) \\
12.1(0.7)\end{array}$ \\
\hline $2,12,12,2$ & $\begin{array}{r}6 \\
8 \\
9 \\
12\end{array}$ & $\begin{array}{l}19 \\
17 \\
15 \\
27\end{array}$ & $\begin{array}{l}119.0(5.3) \\
195.0(15.6) \\
138.0(6.4) \\
134.0(11.5)\end{array}$ & $\begin{array}{l}475.8(10.7) \\
700.0(50.3) \\
388.0(12.5) \\
257.0(2.1)\end{array}$ & $\begin{array}{l}13.8(0.8) \\
16.5(0.3) \\
15.5(0.9) \\
14.2(1.3)\end{array}$ & $\begin{array}{l}16.3(0.8) \\
13.5(0.3) \\
14.5(0.9) \\
15.8(1.3)\end{array}$ & $\begin{array}{l}12.1(0.6) \\
14.4(1.6) \\
14.6(0.8) \\
12.2(0.6)\end{array}$ \\
\hline $12,2,4,2$ & $\begin{array}{r}6 \\
8 \\
9 \\
12\end{array}$ & $\begin{array}{l}18 \\
25 \\
17 \\
20\end{array}$ & $\begin{array}{l}226.5(15.2) \\
464.8(27.9) \\
352.5(25.7) \\
270.6(24.4)\end{array}$ & $\begin{array}{l}295.8(36.6) \\
410.3(29.7) \\
268.8(8.7) \\
229.6(8.0)\end{array}$ & $\begin{array}{l}13.5(1.6) \\
14.5(0.8) \\
14.6(1.0) \\
14.4(0.7)\end{array}$ & $\begin{array}{l}16.5(1.6) \\
15.5(0.8) \\
15.4(1.0) \\
15.6(0.7)\end{array}$ & $\begin{array}{l}12.3(1.1) \\
10.8(0.3) \\
15.6(3.8) \\
10.7(0.2)\end{array}$ \\
\hline $4,2,4,2$ & $\begin{array}{r}6 \\
8 \\
9 \\
12\end{array}$ & $\begin{array}{l}25 \\
22 \\
23 \\
24\end{array}$ & $\begin{array}{l}261.2(10.6) \\
488.2(30.2) \\
236.6(20.6) \\
275.4(5.9)\end{array}$ & $\begin{array}{l}252.0(7.7) \\
334.6(9.1) \\
300.6(22.7) \\
167.8(5.7)\end{array}$ & $\begin{array}{l}13.6(1.0) \\
16.4(1.2) \\
14.8(1.3) \\
16.6(1.3)\end{array}$ & $\begin{array}{l}16.4(1.0) \\
13.6(1.2) \\
15.2(1.3) \\
13.4(1.3)\end{array}$ & $\begin{array}{r}8.9(0.4) \\
9.2(0.5) \\
8.0(0.6) \\
10.3(0.4)\end{array}$ \\
\hline $2,4,4,2$ & $\begin{array}{r}6 \\
8 \\
9 \\
12\end{array}$ & $\begin{array}{l}11 \\
29 \\
23 \\
30\end{array}$ & $\begin{array}{l}345.6(16.9) \\
252.3(12.3) \\
135.4(17.6) \\
172.6(5.8)\end{array}$ & $\begin{array}{l}285.4(21.5) \\
398.5(45.5) \\
383.4(10.5) \\
290.8(14.1)\end{array}$ & $\begin{array}{l}16.6(0.8) \\
16.8(0.7) \\
15.2(1.5) \\
15.6(1.1)\end{array}$ & $\begin{array}{l}13.4(0.8) \\
13.3(0.7) \\
14.8(1.5) \\
14.4(1.1)\end{array}$ & $\begin{array}{l}8.5(0.1) \\
8.2(0.1) \\
7.9(0.2) \\
8.9(0.9)\end{array}$ \\
\hline $2,12,4,2$ & $\begin{array}{r}6 \\
8 \\
9 \\
12\end{array}$ & $\begin{array}{l}18 \\
15 \\
17 \\
12\end{array}$ & $\begin{array}{l}177.0(6.2) \\
164.2(20.1) \\
118.0(11.6) \\
168.0(12.7)\end{array}$ & $\begin{array}{l}338.0(24.7) \\
343.4(15.0) \\
388.6(6.9) \\
337.2(14.4)\end{array}$ & $\begin{array}{l}18.2(0.7) \\
14.4(1.0) \\
16.0(0.8) \\
16.8(1.0)\end{array}$ & $\begin{array}{l}11.8(0.7) \\
15.6(1.0) \\
14.0(0.8) \\
13.2(1.0)\end{array}$ & $\begin{array}{l}10.5(0.3) \\
10.2(0.1) \\
9.5(0.04) \\
10.1(0.4)\end{array}$ \\
\hline $12,2,2,4$ & $\begin{array}{r}6 \\
8 \\
9 \\
6 \\
8 \\
9 \\
12\end{array}$ & $\begin{array}{l}21 \\
22 \\
17 \\
36 \\
18 \\
10 \\
27\end{array}$ & $\begin{array}{l}431.6(8.5) \\
600.6(54.0) \\
380.0(37.5) \\
271.6(10.8) \\
459.6(24.9) \\
450.4(5.9) \\
398.2(28.7)\end{array}$ & $\begin{array}{l}173.4(6.6) \\
258.8(21.2) \\
233.6(12.0) \\
204.8(12.5) \\
268.0(15.6) \\
237.6(3.8) \\
282.8(12.0)\end{array}$ & $\begin{array}{l}16.4(1.0) \\
16.6(1.4) \\
16.4(1.2) \\
12.8(1.4) \\
14.8(0.8) \\
12.8(1.4) \\
14.6(1.3)\end{array}$ & $\begin{array}{l}13.6(1.0) \\
13.4(1.4) \\
13.6(1.2) \\
17.2(1.4) \\
15.2(0.8) \\
17.2(1.4) \\
15.4(1.3)\end{array}$ & $\begin{array}{r}11.1(0.4) \\
12.0(0.3) \\
10.7(0.6) \\
9.8(0.2) \\
8.7(0.2) \\
8.1(0.2) \\
9.0(0.2)\end{array}$ \\
\hline $2,4,2,4$ & $\begin{array}{r}6 \\
8 \\
12\end{array}$ & $\begin{array}{l}25 \\
26 \\
15\end{array}$ & $\begin{array}{l}215.2(20.5) \\
247.2(6.2) \\
290.4(10.5)\end{array}$ & $\begin{array}{l}159.8(13.5) \\
344.2(18.6) \\
280.8(16.0)\end{array}$ & $\begin{array}{l}15.6(1.4) \\
16.0(0.4) \\
16.4(0.8)\end{array}$ & $\begin{array}{l}14.4(1.4) \\
14.0(0.4) \\
13.6(0.8)\end{array}$ & $\begin{array}{l}9.7(0.2) \\
8.3(0.1) \\
6.8(1.3)\end{array}$ \\
\hline $2,12,2,4$ & $\begin{array}{r}6 \\
8 \\
9 \\
12\end{array}$ & $\begin{array}{l}36 \\
18 \\
23 \\
14\end{array}$ & $\begin{array}{l}182.2(18.3) \\
234.6(18.6) \\
129.2(11.3) \\
259.8(20.6)\end{array}$ & $\begin{array}{l}273.8(28.5) \\
390.6(15.5) \\
437.2(41.1) \\
409.2(19.3)\end{array}$ & $\begin{array}{l}16.0(0.9) \\
17.2(1.4) \\
15.6(0.6) \\
15.4(1.2)\end{array}$ & $\begin{array}{l}14.0(0.9) \\
12.8(1.4) \\
14.4(0.6) \\
14.6(1.2)\end{array}$ & $\begin{array}{r}12.0(0.3) \\
9.4(0.2) \\
14.7(4.4) \\
10.5(0.2)\end{array}$ \\
\hline $12,2,2,12$ & $\begin{array}{r}6 \\
8 \\
9 \\
12\end{array}$ & $\begin{array}{l}19 \\
11 \\
14 \\
15\end{array}$ & $\begin{array}{l}361.8(29.3) \\
443.3(20.1) \\
452.8(47.6) \\
589.0(24.0)\end{array}$ & $\begin{array}{l}159.4(10.8) \\
195.8(16.1) \\
240.6(18.5) \\
226.4(11.3)\end{array}$ & $\begin{array}{l}14.8(0.8) \\
15.3(1.3) \\
14.2(0.8) \\
16.4(0.8)\end{array}$ & $\begin{array}{l}15.2(0.8) \\
14.8(1.3) \\
15.8(0.8) \\
13.6(0.8)\end{array}$ & $\begin{array}{l}15.0(0.8) \\
14.3(0.3) \\
12.8(0.2) \\
14.6(0.4)\end{array}$ \\
\hline $4,2,2,12$ & $\begin{array}{r}6 \\
8 \\
9 \\
12\end{array}$ & $\begin{array}{l}26 \\
25 \\
22 \\
23\end{array}$ & $\begin{array}{l}370.4(33.2) \\
604.6(30.7) \\
511.8(22.7) \\
524.4(23.7)\end{array}$ & $\begin{array}{l}162.6(8.6) \\
202.8(12.5) \\
218.8(11.8) \\
160.4(8.1)\end{array}$ & $\begin{array}{l}13.2(0.6) \\
13.6(0.6) \\
14.8(1.0) \\
14.6(0.7)\end{array}$ & $\begin{array}{l}16.8(0.6) \\
16.4(0.6) \\
15.2(1.0) \\
15.4(0.7)\end{array}$ & $\begin{array}{l}13.0(0.3) \\
12.6(0.4) \\
10.4(0.5) \\
12.8(0.4)\end{array}$ \\
\hline $2,4,2,12$ & $\begin{array}{l}6 \\
8\end{array}$ & $\begin{array}{l}15 \\
11\end{array}$ & $\begin{array}{l}276.4(18.0) \\
418.2(10.3)\end{array}$ & $\begin{array}{l}186.2(3.0) \\
205.2(7.3)\end{array}$ & $\begin{array}{l}14.4(1.4) \\
14.8(0.8)\end{array}$ & $\begin{array}{l}15.6(1.4) \\
15.2(0.8)\end{array}$ & $\begin{array}{l}11.6(0.5) \\
11.4(0.3)\end{array}$ \\
\hline
\end{tabular}


APPENDIX (continued)

\begin{tabular}{|c|c|c|c|c|c|c|c|}
\hline \multirow{2}{*}{$\begin{array}{c}\text { Condition* } \\
\left(A_{1}, A_{2}, D_{1}, D_{2}\right) \\
\end{array}$} & \multirow[b]{2}{*}{ Subjects } & \multirow{2}{*}{$\begin{array}{c}\text { Number of } \\
\text { Sessions }\end{array}$} & \multicolumn{2}{|c|}{ Responses per Session } & \multicolumn{2}{|c|}{ Reinforcers per Session } & \multirow{2}{*}{$\begin{array}{c}\text { Session } \dagger \\
\text { Time } \\
\end{array}$} \\
\hline & & & Left & Right & Left & Right & \\
\hline & $\begin{array}{r}9 \\
12\end{array}$ & $\begin{array}{l}16 \\
14\end{array}$ & $\begin{array}{l}434.8(10.3) \\
447.0(18.8)\end{array}$ & $\begin{array}{l}191.8(5.1) \\
165.8(11.2)\end{array}$ & $\begin{array}{l}14.6(0.5) \\
14.4(1.0)\end{array}$ & $\begin{array}{l}15.4(0.5) \\
15.6(1.0)\end{array}$ & $\begin{array}{l}10.2(0.3) \\
12.6(0.5)\end{array}$ \\
\hline $2,12,2,12$ & $\begin{array}{r}6 \\
8 \\
9 \\
12 \\
\end{array}$ & $\begin{array}{l}14 \\
17 \\
36 \\
17\end{array}$ & $\begin{array}{l}215.0(3.4) \\
318.2(18.1) \\
228.6(25.6) \\
418.2(20.7)\end{array}$ & $\begin{array}{l}228.4(12.0) \\
293.6(15.6) \\
286.2(6.6) \\
190.2(7.1)\end{array}$ & $\begin{array}{l}15.4(0.2) \\
15.6(1.3) \\
15.8(1.0) \\
17.2(1.8) \\
\end{array}$ & $\begin{array}{l}14.6(0.2) \\
14.4(1.3) \\
14.2(1.0) \\
12.8(1.8) \\
\end{array}$ & $\begin{array}{l}13.2(0.2) \\
13.5(0.4) \\
11.3(0.4) \\
12.5(0.8) \\
\end{array}$ \\
\hline
\end{tabular}

Note-For the responses and reinforcers per session, and for session time, means of the last 5 days' data are shown with standard errors in parentheses. ${ }^{*} A_{1}, A_{2}, D_{1}, D_{2}$ corresponds to seconds of amount and delay of reinforcement for Alternatives 1 and $2 . \quad+$ Session time in minutes.

(Manuscript received June 24, 1985;

revision accepted for publication November 18,1985 .) 